Artikel Riset

DOI : $10.33751 /$ jf.v9i2.1607
Fitofarmaka Jurnal Ilmiah Farmasi

Vol.9, No.2, Desember $2019: 77-85$

p-ISSN : 2087-9164 e-ISSN : 2622-755X

\title{
FORMULASI EKSTRAK DAN BIJI KOPI ROBUSTA DALAM SEDIAAN MASKER GEL PEEL-OFF UNTUK MENINGKATKAN KELEMBABAN DAN KEHALUSAN KULIT
}

\author{
Asri Wulandari ${ }^{*}$, Erni Rustiani, Ella Noorlaela, Pipih Agustina \\ Program Studi Farmasi FMIPA Universitas Pakuan Bogor, PO Box 452 Bogor 16143 \\ West Java, Indonesia \\ *E-mail: asriwulan43@gmail.com
}

Diterima : 2 Juni 2019

Direvisi : 15 Agustus 2019

Disetujui : 1 September 2019

\begin{abstract}
ABSTRAK
Biji kopi robusta adalah bahan dari tanaman yang berfungsi sebagai antioksidan serta mengandung protein yang dipercaya memiliki khasiat melembabkan dan menghaluskan kulit. Penelitian ini bertujuan untuk menentukan mutu formula gel peeloff dari ekstrak kering dan serbuk biji kopi robusta yang memenuhi syarat. Metode pengujian yang dilakukan meliputi uji organoleptic, viskositas, $\mathrm{pH}$, waktu mengering, dan uji hedonic menggunakan skin analyzer serta verifikasi uji iritasi. Hasil pengujian menunjukkan bahwa F1 merupakan formula terbaik dengan karakteristik gel berwarna coklat tua, aroma kopi dan tekstur sangat halus. Viskositas yang diperoleh $2581 \mathrm{cPs}, \mathrm{pH}$ 7,74 dan waktu mengering gel di kulit selama 18 menit. Hasil uji hedonic menunjukkan bahwa F1 memberi efek terbaik untuk meningkatkan kelembaban dan kehalusan kulit dibandingkan dengan formula lainnya dan tidak mengiritasi.
\end{abstract}

Kata kunci : Biji kopi robusta, Masker gel peel off, Pelembab wajah

\section{FORMULATION GEL PEEL-OFF MASK FROM EXTRACT AND SEEDS ROBUSTA COFFEE TO INCREASE MOISTURIZE AND SMOOTH THE SKIN}

\begin{abstract}
Robusta bean is plant material with high antioxidants potency and contains protein which is effective to moisturize and smooth the skin. This study aims to determine the quality of peel-off gel formula from the extracts and powder of robusta coffee beans. The prepared gel peel-off masks were tested for organoleptic, viscosity, $\mathrm{pH}$, drying time, and hedonic test. The skin moisture and smoothness also was tested using skin analyzer as well as irritation of skin were determined. The results showed that on regard to the quality test, F1 was selected as the most preferred gel peel off mask. The characteristics of gel is dark brown, coffee smell and texture is very smooth. The viscosity obtained is $2581 \mathrm{cPs}, \mathrm{pH} \mathrm{7,74}$ and drying time in the skin surface was 18 minutes. The results of hedonic test show that $\mathrm{F} 1$ gives the best effect to increase the moisture and smoothness of the skin compared to other formulas and does not irritate.
\end{abstract}

Keywords: Robusta coffee, Gel mask, Facial moisturizer. 


\section{PENDAHULUAN}

Kulit merupakan organ esensial dan vital yang mencerminkan kesehatan. Struktur anatomi kulit sangat kompleks, elastis, dan juga sensitif, serta memiliki sifat yang bervariasi bergantung pada keadaan iklim, umur, seks, ras, dan lokasinya tubuh. Pertambahan usia kulit akan mengalami penuaan dengan tandatanda seperti terasa kasar, kusam, berjerawat, bersisik serta timbul bercakbercak (Wasitaatmadja, 1997).

Saat ini kosmetik wajah tersedia dalam berbagai bentuk sediaan, salah satunya adalah masker. Sediaan masker yang banyak terdapat di pasaran salah satunya berbentuk serbuk atau pasta, sedangkan masker dalam bentuk gel masih jarang di jumpai. Masker dengan sediaan gel peel-off mempunyai beberapa keuntungan diantaranya adalah mudah digunakan dan dibilas serta dibersihkan. Selain itu, masker gel peel-off dapat diangkat atau dilepaskan seperti membran elastis (Harry, 2000). Penelitian yang dilakukan oleh Hertina (2013) mengungkapkan bahwa biji kopi sangat baik untuk mengangkat sel-sel kulit mati, melembabkan dan melembutkan kulit. Selain itu, penelitian yang dilakukan oleh Rohmah (2016) mengungkapkan bahwa kulit buah kopi sangat baik untuk perawatan kulit wajah dengan konsentrasi 2,5\% (b/b). Kandungan tanin dalam kulit buah kopi efektif sebagai anti bakteri. Selain itu adanya senyawa polifenol dalam biji kopi sebanyak $0,2 \%$ (b/b) (Najiyati \& Danarti, 2001) menjelaskan potensi kopi sebagai antioksidan yang sangat penting untuk kesehatan kulit wajah (Panggabean, 2012).

Berdasarkan uraian diatas, khasiat biji kopi robusta sebagai antibakteri dan antioksidan akan diformulasikan dalam bentuk masker gel peel-off. Penelitian ini bertujuan untuk membuat masker gel peel-off yang memenuhi syarat dan dapat meningkatkan kelembaban serta kehalusan kulit setelah diaplikasikan.

\section{METODE PENELITIAN Alat dan Bahan}

Alat - alat yang digunakan dalam penelitian adalah grinder $\left(\mathrm{QJH}-\mathrm{Z} 200^{\circledR}\right)$, Viskometer Brookfield (DV-I Prime ${ }^{\circledR}$ ), moisture balance (AND MX-50 ${ }^{\circledR}$ ), homogenizer (IKA RW 20 digital $^{\circledR}$ ), vacum dryer (Ogawa ${ }^{\circledR}$ ), sentrifugator $\left(\right.$ Hettich $\left.^{\circledR}\right)$, tanur $\left(\right.$ VULCAN $\left.^{\circledR}\right)$, pH meter $\left(\right.$ Hanna $\left.^{\circledR}\right)$, silent crusher $\left(\right.$ Heidolph $\left.^{\circledR}\right)$, timbangan analitik $\left(\mathrm{GR}-120^{\circledR}\right)$, ayakan mesh 30, termometer, krus, cawan uap, dan alat-alat gelas lainnya.

Biji kopi robusta yang diperoleh dari Tanjung Sari Puncak, (Bogor). Sedangkan bahan lain yang digunakan yaitu akuades, asam sulfat pekat, asam asetat anhidrat, etanol $96 \%$, polivinil alkohol, hidroksi propil metil selulosa, gliserin, metil paraben, propil paraben, trietanolamin, pereaksi Dragendorff, Mayer, Bouchardat, serbuk magnesium, larutan asam klorida (HCL) pekat dan $2 \mathrm{~N}$, larutan gelatin $1 \%$, larutan buffer $\mathrm{pH}$ 4 dan $\mathrm{pH} \mathrm{7,} \mathrm{larutan} \mathrm{natrium} \mathrm{klorida,}$ metanol pekat $\left(\right.$ Merck $\left.^{\circledR}\right)$.

\section{Pembuatan Ekstrak Kering Biji Kopi Robusta}

Sebanyak $2 \mathrm{~kg}$ serbuk biji kopi robusta yang telah disangrai, dimaserasi dengan 6,7 L etanol 96\% (v/v) selama 24 jam. Filtrat disaring dan residu di remaserasi kembali dengan penambahan 6,7 L etanol 96\% (v/v) sambil sesekali dikocok hingga 3 kali. Pergantian pelarut dilakukan setiap 24 jam sekali setelah proses penyaringan filtrat selama $3 \times 24$ jam. Filtrat yang diperoleh dikumpulkan kemudian di keringkan menggunakan vacum dry (Marlinda et al, 2012). Ekstrak kering yang diperoleh kemudian 
dianalisis mutunya berdasarkan rendemen, kadar air, kadar abu (DepKes RI, 1995), uji fitokimia (Hanani, 2015), dan uji kadar protein (Tejsari, 2005)

\section{Formulasi Masker Wajah Gel Peel-Off Ekstrak dan Serbuk Kopi Robusta}

Masker gel peel-off dibuat sebanyak 5 jenis formula dengan variasi konsentrasi ekstrak kering biji kopi robusta dan serbuk biji kopi robusta. Formula masker peel-off dapat dilihat pada Tabel 1.

Tabel 1. Formula Masker Peel-off

\begin{tabular}{lccccc}
\hline \multirow{2}{*}{ Komposisi } & \multicolumn{5}{c}{ Formula $(\% \mathrm{~b} / \mathrm{b})$} \\
\cline { 2 - 6 } & F0 & F1 & F2 & F3 & F4 \\
\hline Ekstrak kopi robusta & - & 2,5 & 5 & - & - \\
Serbuk kopi robusta & - & - & - & 2,5 & 5 \\
PVA & 10 & 10 & 10 & 10 & 10 \\
HPMC & 1 & 1 & 1 & 1 & 1 \\
Gliserin & 12 & 12 & 12 & 12 & 12 \\
TEA & 2 & 2 & 2 & 2 & 2 \\
Nipagin & 0,2 & 0,2 & 0,2 & 0,2 & 0,2 \\
Nipasol & 0,05 & 0,05 & 0,05 & 0,05 & 0,05 \\
Akuades ad & 100 & 100 & 100 & 100 & 100 \\
\hline
\end{tabular}

Sumber: Panggabean (2012); Septiani et al (2011)

\section{Pembuatan Masker Gel Peel-off Ekstrak dan Serbuk Kopi Robusta}

Ekstrak kering dan serbuk kopi robusta masing-masing dilarutkan dalam akuades. Polivinil alcohol (PVA) (Bahan A) dikembangkan dengan akuades hangat $\left(80^{\circ} \mathrm{C}\right)$ dan diaduk dengan menggunakan homogenizer dengan kecepatan $500 \mathrm{rpm}$. HPMC (Bahan B) dikembangkan dalam akuades. Sedangkan metil paraben dan propil paraben (Bahan C) dilarutkan ke dalam gliserin. Bahan B dan C serta TEA secara simultan berturut-turut dimasukkan kedalam bahan A lalu diaduk sampai homogen menggunakan homogenizer dengan kecepatan $500 \mathrm{rpm}$. Selanjutnya ditambahkan akuades sampai mencapai bobot 100 gram. Sediaan masker gel peel-off ini kemudian dimasukkan kedalam wadah tertutup rapat.

\section{Evaluasi Sediaan Masker Ekstrak dan} Serbuk Kopi Robusta

Uji Evaluasi ediaan

Uji evaluasi sediaan meliputi uji organoleptik yaitu uji warna, aroma, dan tekstur. Uji viskositas dengan menggunakan viskometer Brookfield. Uji $\mathrm{pH}$ dengan alat $\mathrm{pH}$ meter.

\section{Pengujian Waktu Mengering}

Uji waktu mengering sediaan dilakukan dengan cara mengoleskan sediaan sebanyak \pm 1 gram ke punggung tangan dan diamati waktu yang diperlukan sediaan untuk mengering.

\section{Uji Hedonik}

Uji hedonik dilakukan meliputi kesukaan terhadap tekstur, warna, aroma, waktu sediaan mengering, dan uji iritasi. Rentang penilaian adalah 1 : sangat tidak suka, 2: tidak suka, 3: cukup suka, 4: suka, 5: sangat suka. Penilaian penilaian 
panelis terhadap iritasi ditandai dengan poin 6 : terjadi iritasi.

Selanjutnya uji hedonik dilakukan dengan menggunakan skin analyzer, 10 orang panelis dengan kriteria usia 20 tahun keatas, jenis kelamin perempuan, kondisi kulit wajah terdapat flek wajah, kasar, kusam. Pengujian dilakukan selama 1 minggu dengan pemakaian $1 \mathrm{x}$ sehari pada penempatan sediaan dan relawan yang sama. Pada uji ini diamati perubahan tingkat kelembaban dan kehalusan kulit.

Uji verifikasi iritasi dilakukan terhadap 10 orang panelis dengan teknik patch test (tempel terbuka) yang dilakukan dengan mengoleskan sediaan seluas $2,5 \mathrm{~cm}^{2}$ pada lengan kanan atas bagian bawah dan kiri lengan atas bagian bawah untuk basis (F0) sebagai pembanding. (Wasitaatmadja, 1997).

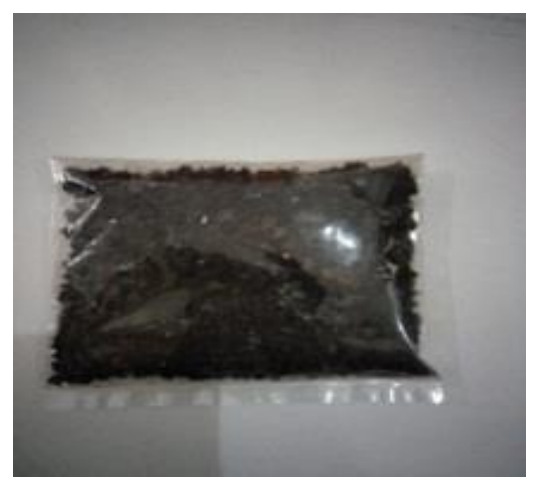

(a)
Diamati terjadi atau tidaknya iritasi pada daerah yang diolesi sediaan tersebut.

\section{HASIL DAN PEMBAHASAN Hasil Pembuatan Ekstrak Kering Biji Kopi Robusta}

Serbuk biji kopi robusta yang dihasilkan memiliki karakteristik warna coklat tua, rasa pahit, dan aroma khas kuat. Sedangkan ekstrak kering biji kopi robusta hasil maserasi memiliki karakteristik yang mirip dengan serbuk bijinya tetapi memiliki morfologi yang berbeda. Secara morfologi serbuk biji kopi robusta memilik tekstur lebih halus dan aroma yang lebih kuat dibandingkan dengan ekstrak kering kopi robusta yang memiliki tekstur lebih kasar dan aroma khas yang lemah. Perbedaan morfologi dari serbuk biji kopi robusta dan ekstrak kering kopi robusta dapat dilihat pada Gambar 1.

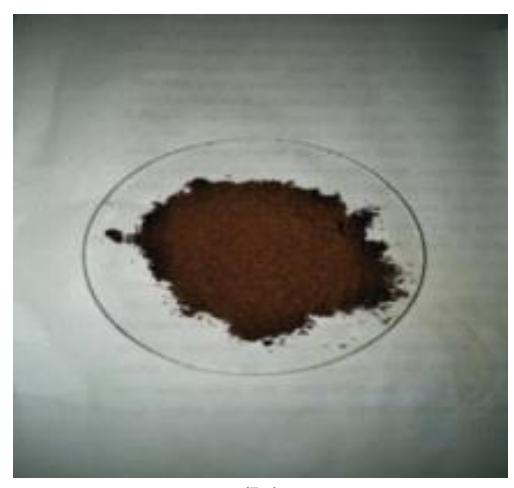

(b)

Gambar 1. (a) Serbuk biji kopi robusta, (b) serbuk ekstrak kering biji kopi robusta

Hasil maserasi serbuk biji kopi robusta menghasilkan ekstrak kering biji kopi robusta dengan rendemen sebesar $7,60 \%(\mathrm{~b} / \mathrm{b})$. Sedangkan hasil evaluasi kadar air menunjukkan bahwa kadar air ekstrak kering biji kopi yang dibuat yaitu sekitar 2,19\% (b/b). Hasil ini memenuhi syarat kadar air pada kopi sangrai menurut DepKes RI (2013). Sedangkan hasil uji kadar abu dari ekstrak kering biji kopi memenuhi syarat SNI 01-28911992 untuk kopi sangrai yaitu sebesar $11,5 \%(\mathrm{~b} / \mathrm{b})$.

Hasil uji fitokimia menunjukkan bahwa biji kopi robusta mengandung senyawa golongan flavonoid, alkaloid, saponin dan tannin, hasil yang diperoleh sesuai dengan penelitian Prasetyo (2015). 
Sedangkan hasil kadar protein pada ekstrak kering biji kopi robusta adalah 29,94\% (b/b). Hasil analisis penelitian ini hampir 2 kali lipat lebih besar dari kandungan protein didalam biji kopi robusta sangrai $13-15 \%$ (Najiyati \& Danarti, 2001). Hal ini disebabkan ekstrak kering biji kopi robusta mengalami proses maserasi dengan perendaman dan pengocokkan yang dapat memisahkan senyawa yang ada dalam biji kopi robusta

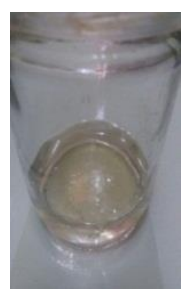

F0

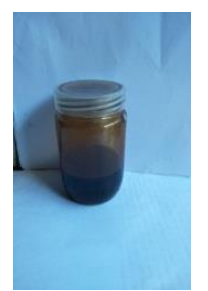

F1

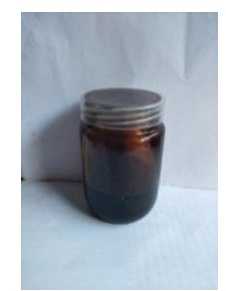

F2

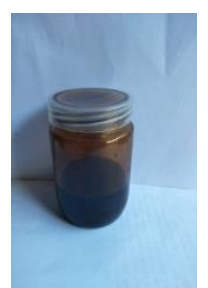

F3

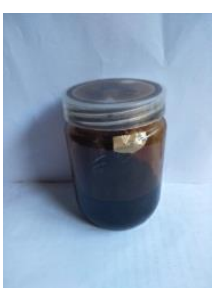

F4
Gambar 2. Hasil Pembuatan Sediaan Gel Peel-off Dari Setiap Formula (F0, F1, F2, F3 dan F4) menentukan nilai kekentalan suatu zat. Semakin kental suatu sediaan maka semakin kecil kecepatan alirannya (Syamsuni, 2005). Nilai viskositas berbanding terbalik dengan daya sebar, artinya semakin tinggi viskositas maka semakin kecil daya sebarnya. Hasil uji viskositas masker gel peel-off ekstrak biji kopi robusta memenuhi syarat standar nilai viskosistas gel yang baik berada pada rentang 2000-4000 cps sedangkan masker gel peel-off serbuk biji kopi robusta tidak memenuhi syarat (Garg et al, 2002). Kekentalan suatu sediaan dapat dipengaruhi oleh adanya penambahan zat aktif yang dapat mempengaruhi nilai viskositas terhadap masker gel yang dibuat. Nilai viskositas masker gel peeloff dapat dilihat pada Gambar 3 .

Uji $\mathrm{pH}$ merupakan salah satu parameter penting dalam analisis produk, karena $\mathrm{pH}$ dari sediaan yang dipakai
Uji viskositas bertujuan untuk

\section{Evaluasi Sediaan Masker Ekstrak dan Serbuk Biji Kopi Robusta}

Hasil uji organoleptik basis gel memiliki karakteristik bening, tidak berbau, dan tekstur halus. Sediaan masker gel peel-off yang dihasilkan dari semua formula memiliki organoleptik yang sama yaitu berwarna coklat tua, aroma khas kopi, tekstur halus, sedikit berbutir pada formula serbuk. Hasil pembuatan sediaan dapat dilihat pada Gambar 2. dapat mempengaruhi daya absorpsi kulit. Syarat $\mathrm{pH}$ sediaan gel yakni harus sesuai dengan pH kulit, yaitu antara 4,5-6,5 (Saib, 2010). Apabila terlalu basa dapat menyebabkan kulit kering dan bersisik, sedangkan jika terlalu asam dapat menyebabkan iritasi pada kulit (Wasiaatmadja, 1997). Nilai $\mathrm{pH}$ masker gel peel-off dapat dilihat pada Gambar 4.

Hasil uji sediaan mengering masker gel peel-off ekstrak kopi robusta lebih cepat mengering. dibandingkan dengan sediaan masker gel serbuk biji kopi robusta. Perbedaan waktu mengering dapat disebabkan oleh sifat zat aktif yang ditambahkan dalam sediaan dan perbedaan jenis kulit panelis. Waktu yang dihasilkan masih berada pada rentang waktu kering dari produk inovator masker yang ada dipasaran, yaitu antara 10 - 30 menit (Vieira, 2009). Nilai waktu mengering masker gel peel-off dapat dilihat pada Gambar 5. 


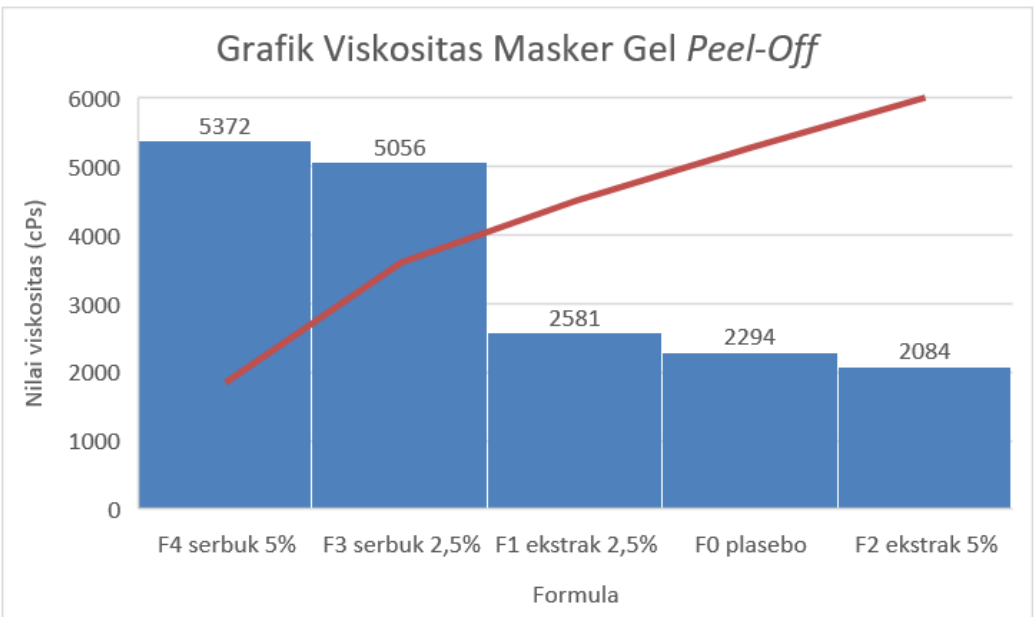

Gambar 3. Nilai Viskositas Masker Gel Peel-off Dari Setiap Formula

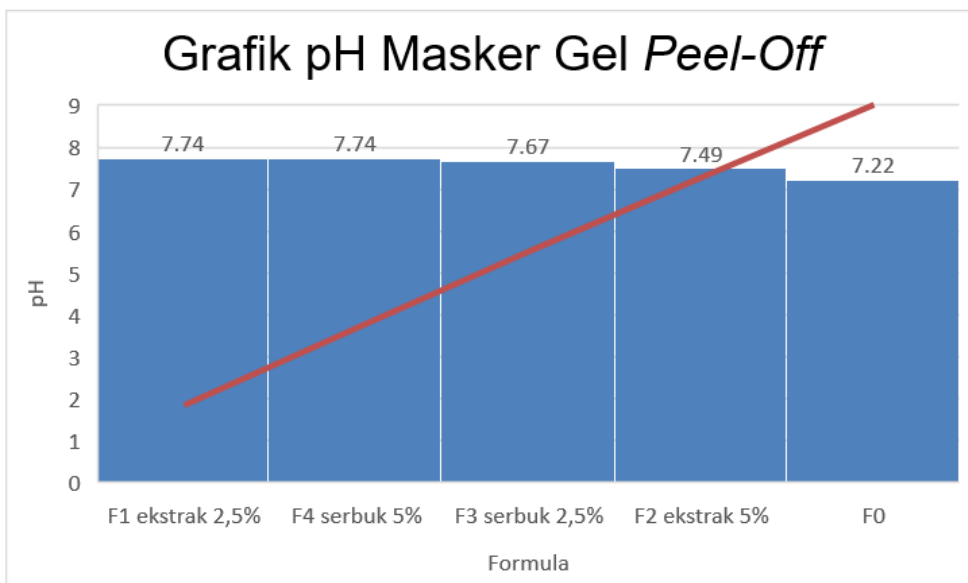

Gambar 4. Nilai pH Masker Gel Peel-off Dari Setiap Formula

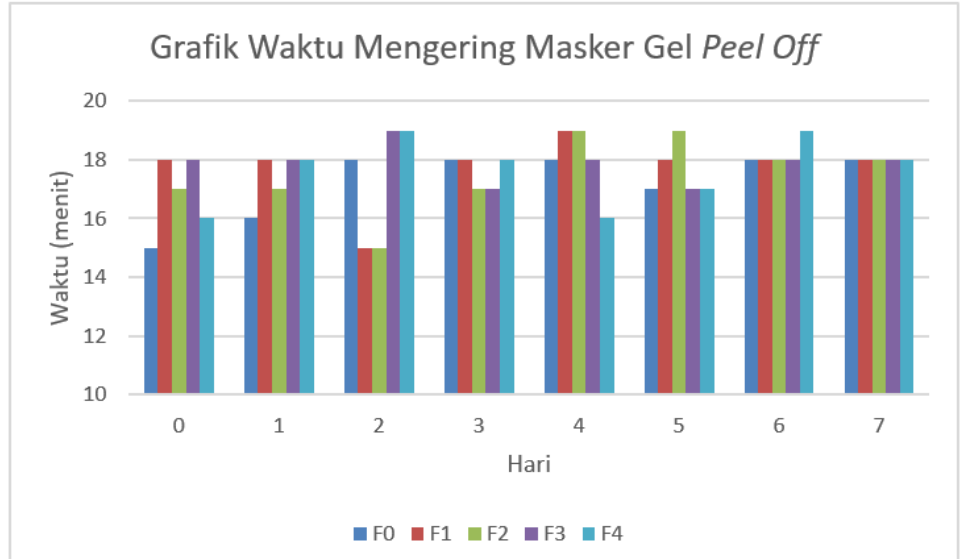

Gambar 5. Nilai Waktu Mengering Masker Gel Peel-off Dari Setiap Formula 
Hasil uji hedonik daya terima panelis memberikan pengaruh yang berbeda pada setiap formula sediaan. Hasil uji hedonik terhadap tekstur menunjukan bahwa F1 memiliki daya terima yang baik. Hal ini disebabkan kandungan ekstrak biji kopi robusta lebih sedikit sehingga tekstur yang dihasilkan lebih lembut dibandingkan formula dengan bahan aktif serbuk biji kopi robusta yang memiliki sedikit berbutir. Hasil uji hedonik terhadap warna menunjukan bahwa $\mathrm{F} 1$ paling disukai sedangkan F0 cukup disukai. Hasil uji hedonik terhadap aroma menunjukan bahwa F4 paling disukai karena bahan aktif yang digunakan serbuk biji kopi dengan konsentrasi besar sehingga aroma yang dihasilkan lebih kuat. Hasil uji hedonik terhadap waktu mengering menunjukan bahwa $\mathrm{F} 1$ paling disukai. Hasil uji hedonik terhadap uji iritasi menunjukan bahwa F0 dan F2 menimbulkan iritasi berupa kemerahan, gatal, dan terasa panas sedangkan F1, F3, dan F4 tidak menimbulkan iritasi. Nilai hasil uji hedonic dapat dilihat pada Gambar 6.

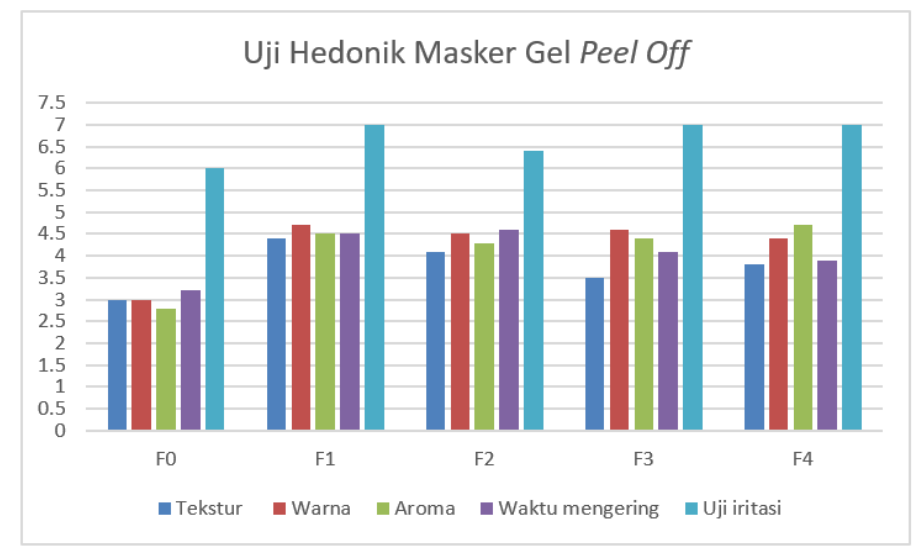

Gambar 6. Hasil Uji Hedonik Daya Terima Masker Gel Peel-off Dari Setiap Formula

Hasil hedonic menggunakan skin analyzer pada formula F0, F1, F2, F3, dan F4 menunjukkan bahwa terdapat perbedaan sebelum dan setelah pemakaian sediaan yang dapat dilihat pada tingkat kelembaban pada sukarelawan tiap harinya. Pada tiap sukarelawan terjadi peningkatan kelembaban yang berbeda tiap formulanya selama pemberian sediaan masker gel peel-off. Hasil yang di amati terhadap sukarelawan rata-rata berminyak dan kering, tetapi dengan adanya perawatan kulit wajah memiliki perubahan. Berdasarkan hasil uji skin analyzer ini dapat disimpulkan bahwa F1 yang mengandung ekstrak kopi 2,5\% dan F4 yang mengandung serbuk kopi 5\% memiliki tingkat kelembaban dan kehalusan kulit yang tinggi. Hasil ratarata skin analyzer dapat dilihat pada Tabel 2. 
Tabel 2. Hasil Skin Analyzer Masing-masing Formula

\begin{tabular}{cccccccccccc}
\hline & \multicolumn{8}{c}{ F } & \multicolumn{9}{c}{ Ferlakuan } \\
\hline \multirow{2}{*}{ Analisis } & \multicolumn{2}{c}{ F0 } & \multicolumn{2}{c}{ F1 } & \multicolumn{2}{c}{ F2 } & & F3 & \multicolumn{2}{c}{ F4 } \\
\cline { 2 - 13 } & SP & ST & SP & ST & SP & ST & SP & ST & SP & ST \\
\hline Moisturizer & -1.7 & -0.4 & -1.6 & 3.9 & -3 & 3.8 & -1.2 & 3.8 & -0.7 & 4.0 \\
\hline Oil & -0.1 & -0.0 & -1.7 & 1.9 & -2 & 1.9 & -1.4 & 2 & -0.9 & 1.9 \\
\hline Soft & -0.4 & -0.3 & -0.8 & 3.6 & -1.2 & 3.8 & -1.3 & 3.7 & -1.3 & 3.2 \\
\hline
\end{tabular}

Keterangan :

SP: Sebelum Perlakuan

1. Moisturizer

- Kering

- Normal

$:-5,-4,-3,-2$

- Moisturizer

$:-1,0,1$

2. Oil

- Sangat moisturizer $\quad: 4,5$

- Kering : $-5,-4,-3,-2$

- Normal : $-1,0,1$

- Oil :2, $3,4,5$

\section{KESIMPULAN}

1. Formula terbaik masker gel peeloff biji kopi robusta adalah F1 dengan konsentrasi ekstrak biji kopi robusta $2,5 \%$ yang efektif untuk meningkatkan kelembaban dan kehalusan kulit wajah.

2. Hasil evaluasi F1 memenuhi syarat farmaseutik dengan karakteristik sediaan berwarna coklat tua, aroma khas kopi dan tekstur sangat halus. Nilai viskositas $2581 \mathrm{cPs}, \mathrm{pH}$ 7,74, waktu mengering 18 menit dan tidak mengiritasi kulit.

\section{REFERENSI}

Departemen Kesehatan RI. 1995. Farmakope Indonesia Edisi IV. Direktorat Jenderal Pengawasan Obat dan Makanan. Jakarta.

2013. Farmakope Herbal Indonesia. Direktorat Jenderal Pengawasan Obat dan Makanan. Jakarta.

Garg, A. D., Aggarwal, S., Garg \& A. K. Sigla. 2002. Spreading of
ST : Setelah Perlakuan

3. Ronght dan Soft

Sangat kasar : $-5,-4,-3$

Kasar : $-2,-1$

Normal : 0,1

Halus : 2, 3

Sangat halus $: 4,5$

Semisolid Formulation.

Pharmaceutical Technology. Aster Publishing Corp.

Hanani, E. 2015. Analisis Fitokimia. EGC Press. Jakarta.

Hertina, N.T. 2013. Pemanfaatan ampas kedelai putih dan ampas kopi dengan perbandingan berbeda dalam pembuatan lulur tradisional untuk perawatan tubuh. Skripsi. Universitas Negeri Surabaya. Surabaya.

Harry \& Ralph. G. 2000. Harry's Cosmeticology Edisi VI. Chemical Publishing. New York.

Marlinda, M., Meiskes., S. \& Audym, D. W. 2012. Analisis senyawa metabolit sekunder dan uji toksisitas ekstrak etanol biji alpukat (Persea Americana Mill). Skripsi. Universitas Sam Ratulangi.

Najiyati, S. \& Danarti, D. 2001. Kopi: Budidaya dan Penanganan Lepas Panen. Penebar Swadaya. Jakarta.

Panggabean, E. 2012. The Secret of Barista. PT Wahyumedia. Jakarta. 
Prasetyo, H. 2015. Ekstraksi senyawa antioksidan kulit buah kopi: kajian jenis kopi dan lama maserasi. Skripsi. Universitas Jember.

Rohmah, A.R. 2016. Pengaruh proporsi kulit buah kopi dan oatmeal terhadap hasil jadi masker tradisional untuk perawatan kulit wajah. e-Journal Universitas Negeri Surabaya. 05 (03):72-79.

Saib, N. F. 2010. The Effect of Addition of Antioxidant to The Stability of Green Tea Water Extracts As Anti Acne. Indonesian Journal of Cancer Chemoprevention. 1(1) : 48.

Septiani, S., Wathoni, N. \& Mita, S.R. 2011. Formulasi sediaan masker gel antioksidan dari ekstrak etanol biji melinjo (Gnetum gnemon Linn). Students e-jurnal. Fakultas Farmasi Universitas Pajajaran 1(1):1-26.

Syamsuni, H. A. 2005. Ilmu Resep. EGC Press. Jakarta.

Tejasari. 2005. Nilai Gizi Pangan. Penerbit Graha Ilmu. Yogyakarta.

Vieira, R.P. 2009. Physical and physicochemical stability evaluation of cosmetic formulation containing soybean extract fermented by Bifido bacterium animals. Braz. J. Pharm. Sci. 45(3): 515-525.

Wasitaatmadja, S. M., 1997. Penuntun Ilmu Kosmetik Medik. Penerbit Universitas Indonesia. Jakarta. 